\title{
An influence of mesohabitat structures (pool, riffle, and run) and land-use pattern on the index of biological integrity in the Geum River watershed
}

\author{
Martha S. Calderon and Kwang-Guk $A n^{*}$
}

\begin{abstract}
Background: Previous studies on the biological integrity on habitat and landuse patterns demonstrated ecological stream health in the view of regional or macrohabitat scale, thus ignored the mesoscale habitat patterns of pool, riffle, and runs in the stream health analysis. The objective of this study was to analyze influences on the mesohabitat structures of pool, riffle, and run reaches on the fish guilds and biological integrity in Geum-River Watershed.

Results: The mesohabitat structures of pool, riffle, and run reaches influenced the ecological stream health along with some close relations on the fish trophic and tolerance guilds. The mesoscale components altered chemical water quality such as nutrients (TN, TP) and BOD and these, then, determined the primary productions, based on the sestonic chlorophyll-a. The riffle-reach had good chemical conditions, but the pool-reach had nutrient enrichments. The riffle-reach had a predominance of insectivores, while the pool-reach has a predominance of omnivores. Also, the riffle-reach had high proportions of sensitive fish and insectivore fish, and the pool-reach had high proportions of tolerant species in the community composition. The intermediate fish species in tolerance and omnivorous fish species in the food linkage dominated the community in the watershed, and the sensitive and insectivorous fishes decreased rapidly with a degradation of the water quality. All the habitat patterns were largely determined by the land-use patterns in the watershed.
\end{abstract}

Conclusions: Trophic guilds and tolerance guilds of fish were determined by land-use pattern and these determined the stream health, based on the Index of Biological Integrity. This study remarks the necessity to include additional variables to consider information provided by mesohabitats and land-use distributions within the selected stream stretch. Overall, our data suggest that land-use pattern and mesohabitat distribution are important factors to be considered for the trophic and tolerance fish compositions and chemical gradients as well as ecological stream health in the watershed.

Keywords: Mesohabitat, Land-use pattern, Water chemistry, Multi-metric fish model, Stream health

* Correspondence: kgan@cnu.ac.kr

Department of Biological Sciences, College of Biological Sciences and

Biotechnology, Chungnam National University, Daejeon 34134, South Korea 


\section{Background}

The model development and assessments of stream ecosystem health has been one of the hot issues in stream conservation and restorations in worldwide aquatic ecosystems. The health assessment model of index of biological integrity (IBI), based on fish community, was developed by Karr (1981) and then applied to numerous waterbodies of North America, Oceania (Harris 1995; Harris and Silveira 1999), Europe (Oberdorff and Hughes 1992; Schmutz et al. 2007), Africa, and Asia (Hocutt et al. 1994; Hugueny et al. 1996; Ganasan and Hughes 1998) after regional modifications of the multimetric model. These assessments provided key clues for stream/river conservations (Griffith et al. 2005; Pichon et al. 2006) as well as diagnosis of the river health conditions (Plafkin et al. 1989; Kennard et al. 2005; Roset et al. 2007). Thus, regional modifications of the model were widely discussed (Kleynhans 1999; European Commission 2000; Jaramillo-Villa and Caramaschi 2008; Zhu and Chang 2008).

The advantage of the IBI approach is low spatial and temporal variability due to high trophic position in the food chain of aquatic ecosystems and has a potential to integrate various aspects of the habitat on multiples scales (Karr et al. 1986; Machado et al. 2011). For this reason, applications of multi-metric models were successful in the managements and conservations of stream ecosystems. Fish abundance and distributions in the stream ecosystems, however, had large variations in the levels of microhabitat or mesoscale habitat (Langeani et al. 2005), resulting in large variations in stream health assessments and ecological predictions of stream ecosystem degradations using some simulation models. Although it has been reported that fish respond to different types of mesohabitats (Gelwick 1990; Langeani et al. 2005; Kennard et al. 2005), this information was not directly considered in the fish biotic indices previously proposed, and the IBI protocols were assessed over an entire stream rather than reach or specific site (covering about $200 \mathrm{~m}$ ). Thus, ecological responses to the disturbance or chemical pollutions were irregular in a particular way in each mesohabitat type over or underestimating certain metrics if the stretch is considered as a whole (Casatti and Teresa 2012; Teresa and Casatti 2010).

In this study, we selected the mesohabitat structures of pool, riffle, and run from the watershed of the Geum River, which is the third largest river basin in Korea. This watershed is located on the west of the central part of the Korean peninsula (Chungnam Province) and the upper region is mainly located in the forest region. In contrast, urban and agricultural regions are located in the mid- to downstream regions. The river flows into the west sea and total length of the river is $395.9 \mathrm{~km}$ along with a total river area of $9835.3 \mathrm{~km}^{2}$. For these reasons, the river is the largest water source for drinking water and agricultural and industrial uses in the province (Noh et al. 2015). It has been reported that several tributaries deliver most nutrients or contaminants into the main channel of the Geum River. One of the major tributaries is the Gap Stream which flows through the city of Daejeon and is known to be the largest source of contaminants affected by effluent from a sewage disposal plant and wastewater discharge from an industrial complex (Chung et al. 2008; Shim et al. 2015). Miho Stream, another major tributary adjacent to the city of Chungjoo, is similarly influenced by a nearby sewage treatment plant located near the urban (Lee and Hwang 2013; Shim et al. 2015).

Currently, the Geum River watershed has two artificial dams of Yongdam Dam and Daecheong Dam. The dam constructions influenced the accumulation of sediments and mesoscale habitat structures of pool, riffle, and run as well as chemical water quality. The dams decreased river flow and, as a result, increased the accumulation of fine sediments (silt and clay) on the downstreams, which adsorb more organic matter (OM) and metals, due to their larger surface area (Shim et al. 2015). The patterns of land uses within a watershed also influenced various intrinsic attributes of the Geum River system, including hydrological, geomorphological, chemical, and biological features such as fish assemblages (Lee, Hwang, et al. 2011b; Machado et al. 2011). Also, changes in the hydrological cycle and material inputs by differences of land-use patterns of the watershed may have negative consequences in fish assemblages or trophic structures (Machado et al. 2011). Removing native vegetation and building artificial barriers in the artificial weirs and dams decreased heterogeneous habitats and restrict fish movement, resulting in modifications of population viability and biotic integrity of the watershed (Pichon et al. 2006; Machado et al. 2011).

In this study, we analyzed some influences of mesohabitat structures of pool, riffle, and run reach on the IBI using fish assemblages and along with the influences of the land-use pattern on the IBI in Geum River watershed. For the study, we analyzed the water quality data and stream ecosystem health using a multi-metric fish model of the IBI in the sampling sites. In addition, we expanded the application of IBI to mesohabitat structures and land-use pattern along with chemical impacts on the ecological health conditions.

\section{Methods}

\section{Sampling sites and fish collection}

Sampling fishes were conducted at 150 sites along the Geum River watershed during April-May 2010 following the wading method suggested by Ohio (1989). Fishes were sampled in an upstream direction for a distance of 


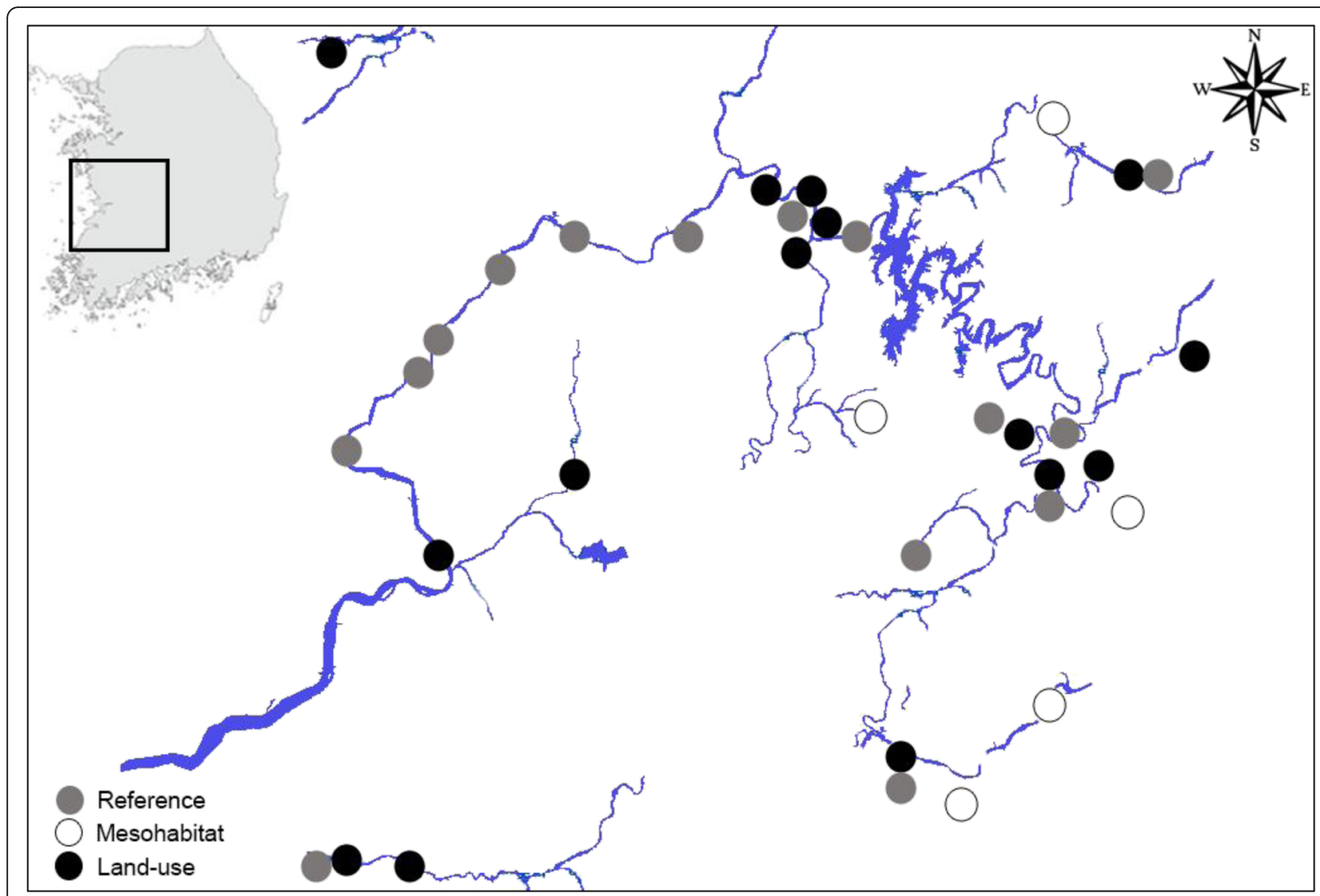

Fig. 1 Sampling sites, based on the mesohabitat (white circle) and the land-use pattern (dark circle) in the Geum River watershed along with reference sites (gray circle)

Table 1 Fish community metrics, score values, and the index of biological integrity (IBI) for each group in the mesohabitats and land-use pattern

\begin{tabular}{|c|c|c|c|c|c|c|c|c|}
\hline \multirow[t]{2}{*}{ Category } & \multirow[t]{2}{*}{ Model metrics } & \multirow{2}{*}{$\begin{array}{l}\text { Expected } \\
\text { response }\end{array}$} & \multicolumn{3}{|c|}{ Mesohabitat pattern } & \multicolumn{3}{|c|}{ Land-use pattern } \\
\hline & & & $\mathrm{R}_{\mathrm{i}}-\mathrm{D}_{\mathrm{s}}(n=5)$ & $\mathrm{R}_{\mathrm{u}}-\mathrm{D}_{\mathrm{s}}(n=5)$ & $P_{\mathrm{o}}-D_{\mathrm{s}}(n=5)$ & $\mathrm{F}_{\mathrm{o}}-\mathrm{L}(n=5)$ & $A_{g}-L(n=5)$ & $U_{r^{-}-L}(n=5)$ \\
\hline \multirow{4}{*}{$\begin{array}{l}\text { Ecological characteristics: } \\
\text { species richness and } \\
\text { composition }\end{array}$} & $\begin{array}{l}\text { M1: total number of native } \\
\text { species }\end{array}$ & Decrease & $4.6 \pm 0.89$ & $3.4 \pm 1.67$ & $1.4 \pm 0.89$ & $4.6 \pm 0.89$ & $3.4 \pm 1.67$ & $2.2 \pm 1.09$ \\
\hline & $\begin{array}{l}\text { M2: total number of } \\
\text { riffle-benthic species }\end{array}$ & Decrease & $3 \pm 1.41$ & $1.8 \pm 1.09$ & $1 \pm 0$ & $3 \pm 1.41$ & $1.4 \pm 0.89$ & $1 \pm 0$ \\
\hline & $\begin{array}{l}\text { M3: total number of } \\
\text { sensitive species }\end{array}$ & Decrease & $4.2 \pm 1.09$ & $1.8 \pm 1.09$ & $1 \pm 0$ & $4.2 \pm 1.09$ & $1.4 \pm 0.89$ & $1 \pm 0$ \\
\hline & $\begin{array}{l}\text { M4: proportion of } \\
\text { individuals as tolerant } \\
\text { species }\end{array}$ & Increase & $3.4 \pm 1.67$ & $1 \pm 0$ & $1 \pm 0$ & $3.4 \pm 1.67$ & $1 \pm 0$ & $1 \pm 0$ \\
\hline \multirow[t]{2}{*}{ Trophic composition } & $\begin{array}{l}\text { M5: proportion of } \\
\text { individuals as omnivore }\end{array}$ & Increase & $4.6 \pm 0.89$ & $1.8 \pm 1.09$ & $3 \pm 2$ & $4.6 \pm 0.89$ & $1.4 \pm 0.89$ & $1.8 \pm 1.09$ \\
\hline & $\begin{array}{l}\text { M6: proportion of } \\
\text { individuals as insectivores }\end{array}$ & Decrease & $5 \pm 0$ & $4.2 \pm 1.09$ & $3 \pm 2$ & $5 \pm 0$ & $2.2 \pm 2.19$ & $3.4 \pm 1.67$ \\
\hline \multirow[t]{2}{*}{$\begin{array}{l}\text { Fish abundance and health } \\
\text { condition }\end{array}$} & $\begin{array}{l}\text { M7:total number of } \\
\text { individuals }\end{array}$ & Increase & $4.6 \pm 0.89$ & $1.4 \pm 0.89$ & $1.4 \pm 0.89$ & $4.6 \pm 0.89$ & $2.6 \pm 2.19$ & $1 \pm 0$ \\
\hline & $\begin{array}{l}\text { M8: proportion of } \\
\text { abnormal individual }\end{array}$ & Increase & $4.6 \pm 0.89$ & $4.2 \pm 1.78$ & $5 \pm 0$ & $4.6 \pm 0.89$ & $3.4 \pm 1.78$ & $3.4 \pm 2.19$ \\
\hline Model values of |BI & & & $34 \pm 0.65$ & $19.6 \pm 1.19$ & $16.8 \pm 1.35$ & $34 \pm 0.65$ & $16.8 \pm 0.88$ & $14.8 \pm 0.98$ \\
\hline Mean $|\mathrm{B}|$ & & & $22.6 \pm 8.13$ & & & & & \\
\hline Criteria of ecological health & & & Good-Fair & Fair-Poor & Poor-very poor & Good-Fair & Poor-very poor & Poor-very poor \\
\hline
\end{tabular}


at least 150-200 m during $50 \mathrm{~min}$ (An et al. 2002). All specimens were preserved in $10 \%$ formalin and returned to the laboratory to identify the taxa. Sensitive and tolerant species were classified based on the previous studies of $\operatorname{Kim}(1995,1997)$. All fishes were examined for external deformities, erosion (skin, barbells), lesion (open sores, ulcerations), and tumors (DELT anormalies), based on the criteria of Sanders et al. (1999).

\section{Selection of mesoscale habitats and land-use pattern}

From the total stations, we selected 15 sites as dominated by riffles $\left(R_{i}-D_{s}\right)$, runs $\left(R_{u}-D_{s}\right)$, and pools $\left(P_{o}-D_{s}\right)$, distinguishable according to depth, substrate composition, and flow; each one considered a mesohabitat. Riffles were shallow, with a rocky or gravelly substrate and a strong to moderate current. Pools had a greater depth, an unconsolidated (litter) or sandy substrate, and a slow stream flow (near zero), while runs had intermediate values of these parameters, i.e., a moderate depth and current and a sandy substrate (Casatti and Teresa 2012; Gosselin et al. 2012). Additionally, 15 sites were grouped into three classes of increasing relative human impact: forest $\left(\mathrm{F}_{\mathrm{o}}-\mathrm{L}\right)$, agricultural $\left(\mathrm{A}_{\mathrm{g}}-\mathrm{L}\right)$, and urban $\left(\mathrm{U}_{\mathrm{r}}-\mathrm{L}\right)$, based on watershed and riparian land use (Fig. 1). In this study, sampling were stations classified as forest area, which was generally located in the headwater pristine regions of the watershed, and agricultural and urban lands were rare in the land composition. Agricultural lands dominated near the mid-and downstream region of the watershed and were consisted of cropland, feedlot/barnyard, orchard, and pasture. In contrast, urban area included non-farm residential, commercial, transportation, and
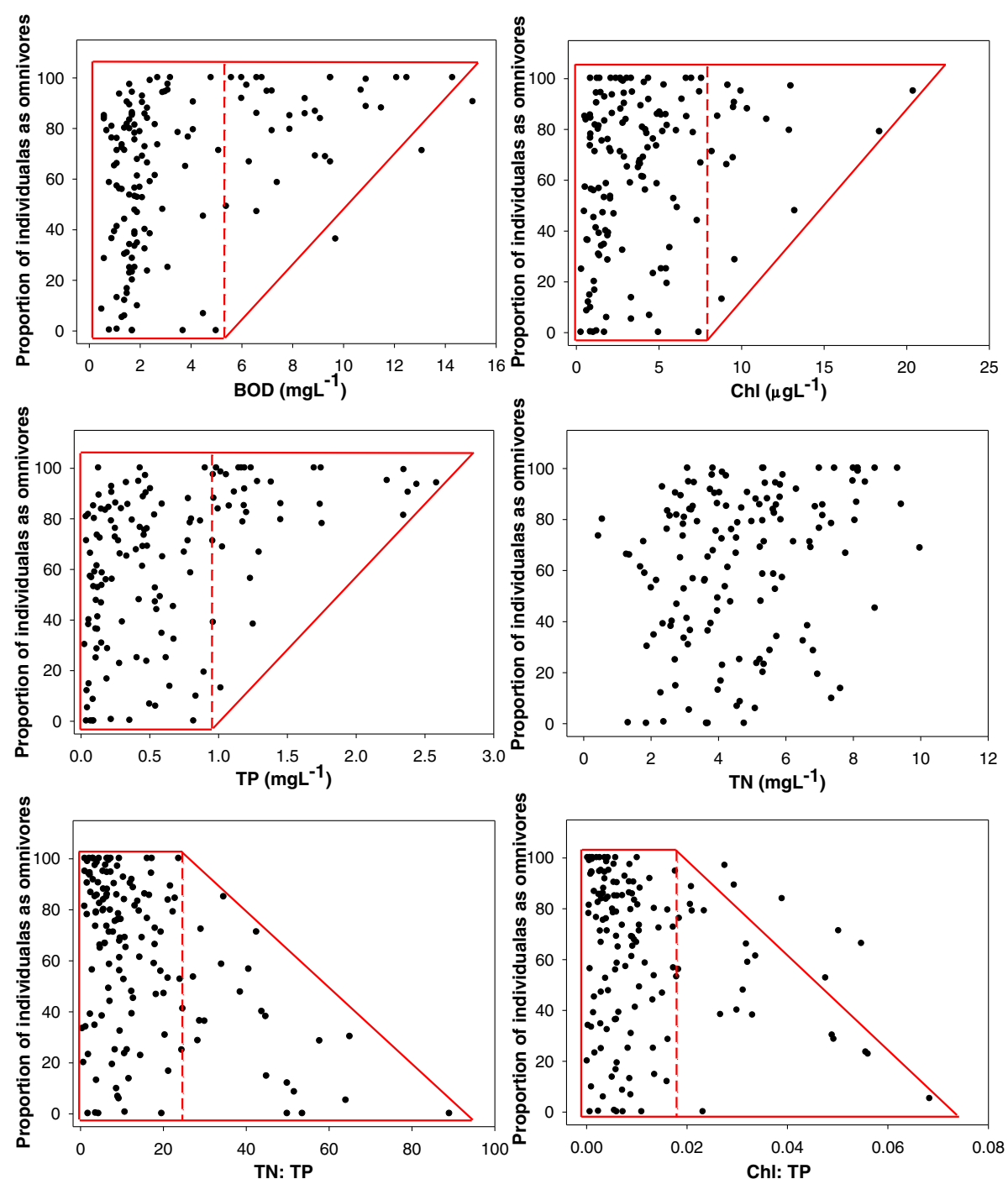

Fig. 2 The relations of omnivore fish, as a number of individuals, to chemical water quality parameters in 150 sampling sites in Geum River watershed 
industrial area, and the region was located near Daejeon city and Chungju city with wastewater treatment plants and industrial complex.

We also selected reference sites as shown in Fig. 1, and the reference sites were selected from the pristine regions, based on the least impacted areas affected by as little human interference as possible on regional and site-specific scales (Hughes 1995).

\section{Chemical Parameters and Data Analysis}

Nutrient data of total nitrogen (TN) and total phosphorus (TP) in the Geum River watershed were analyzed along with biological oxygen demand (BOD) and chlorophyll-a (Chl), obtained from the Water Information System, Ministry of Environment, Korea. Total phosphorus (TP) was determined using the ascorbic acid method after persulfate oxidation (Prepas and Rigler 1982) and total suspended solids (TSS) were filtered by GF/C filers and measured by APHA (1999). Chlorophyll-a concentration was measured by using a spectrophotometer after extraction in hot ethanol (Sartory and Grobbelaar 1984). We followed the eight-metric system for the IBI suggested by An et al. (2006), which includes categories as species richness and composition, trophic composition, and fish abundance and health condition (Table 1). Each metric was scored 5, 3 , or 1 , and the final IBI calculation for each mesohabitat was obtained from the average value of all scores for each group of samples and classified in terms of four categories of biotic integrity, i.e., excellent (36-40), good (28-34), fair (20-26), poor (14-18), and very poor (8-13) (An et al. 2006). To evaluate the effect of
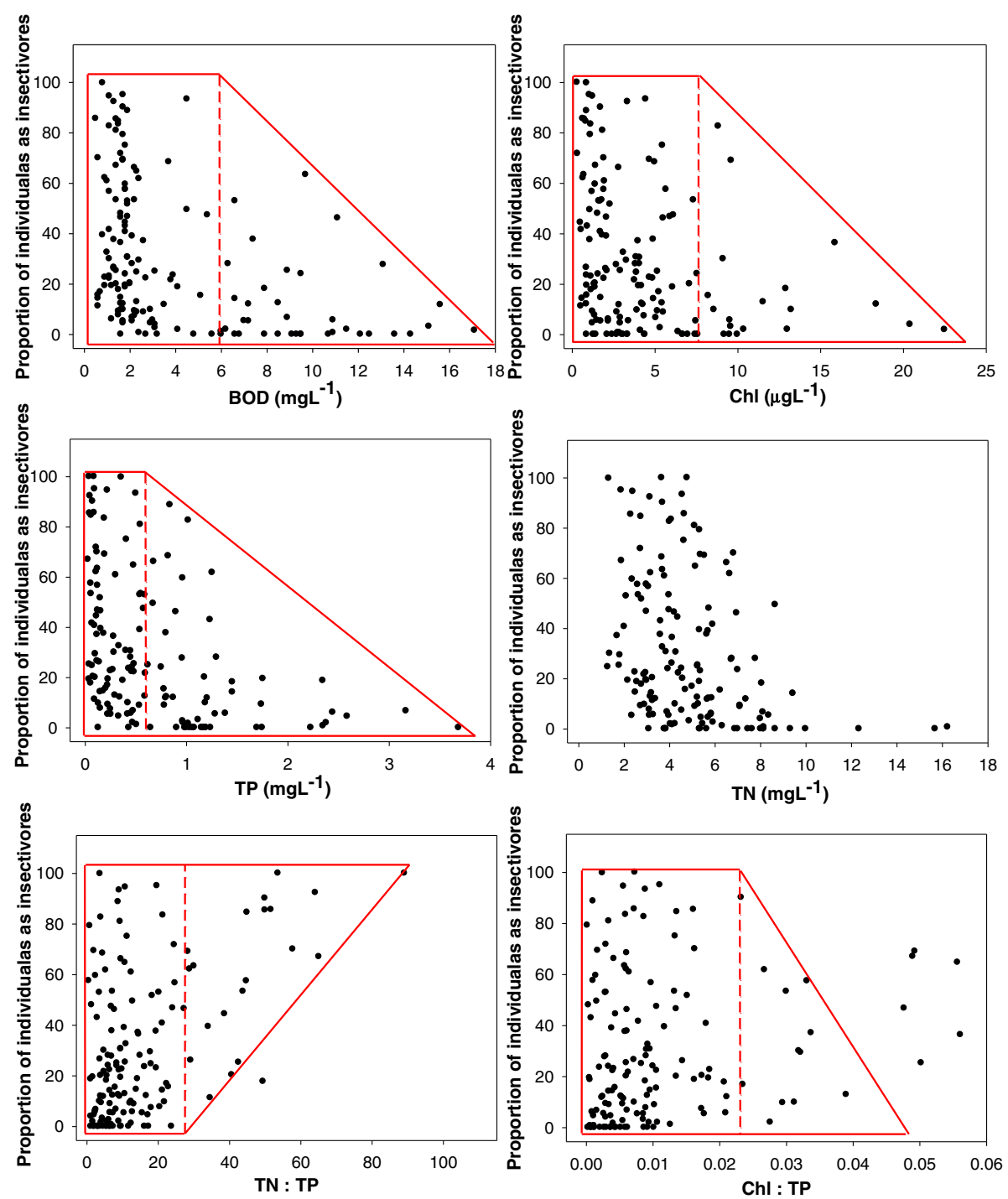

Fig. 3 The relations of omnivore fish, as a number of individuals, to chemical water quality parameters in 150 sampling sites 

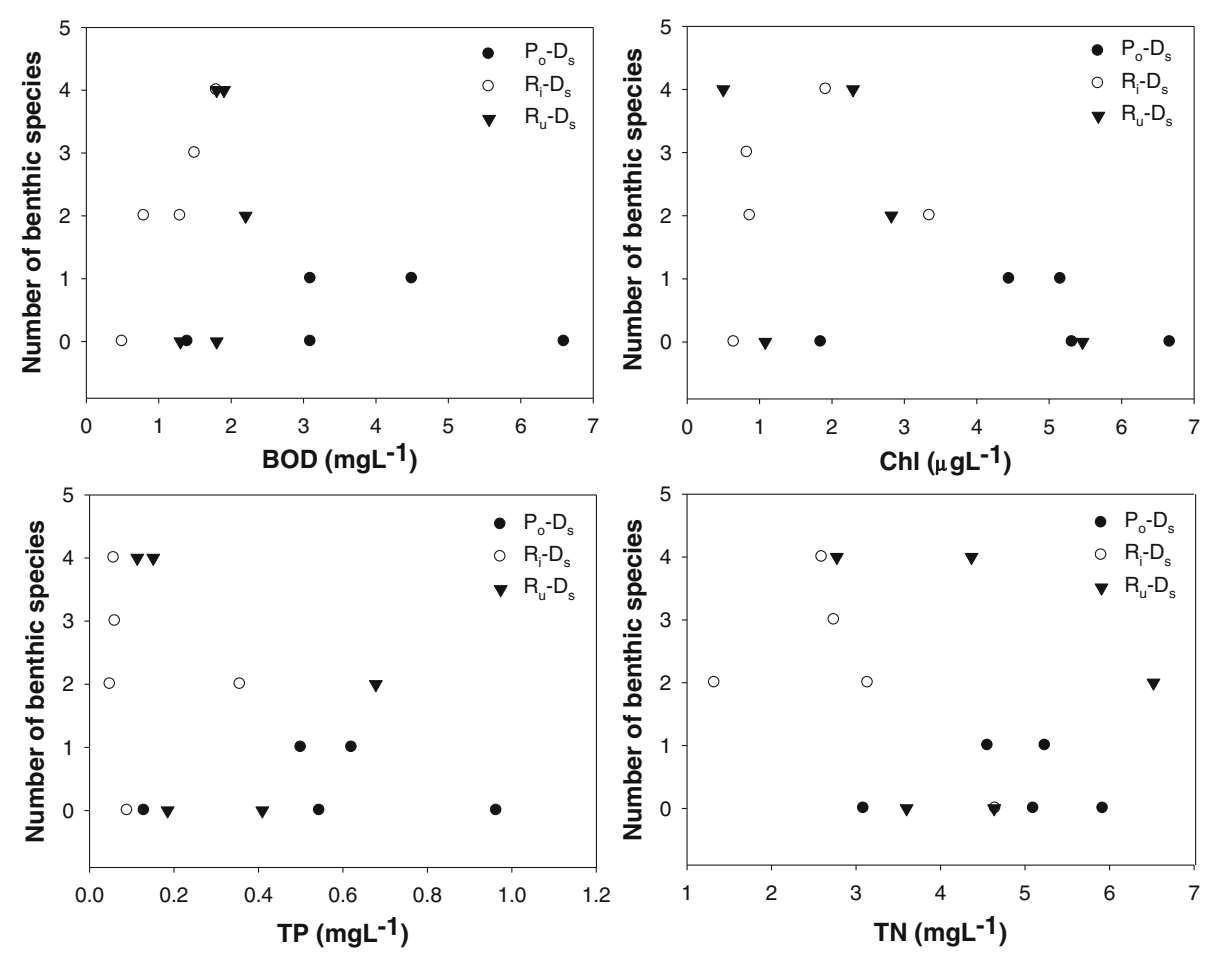

Fig. 4 Percentage of benthic fish observed in three mesohabitats of pools $\left(P_{\mathrm{o}}-D_{\mathrm{s}}\right)$, riffles $\left(R_{\mathrm{i}}-D_{\mathrm{s}}\right)$, and runs $\left(R_{\mathrm{u}}-D_{\mathrm{s}}\right)$ in a gradient of chemical water quality
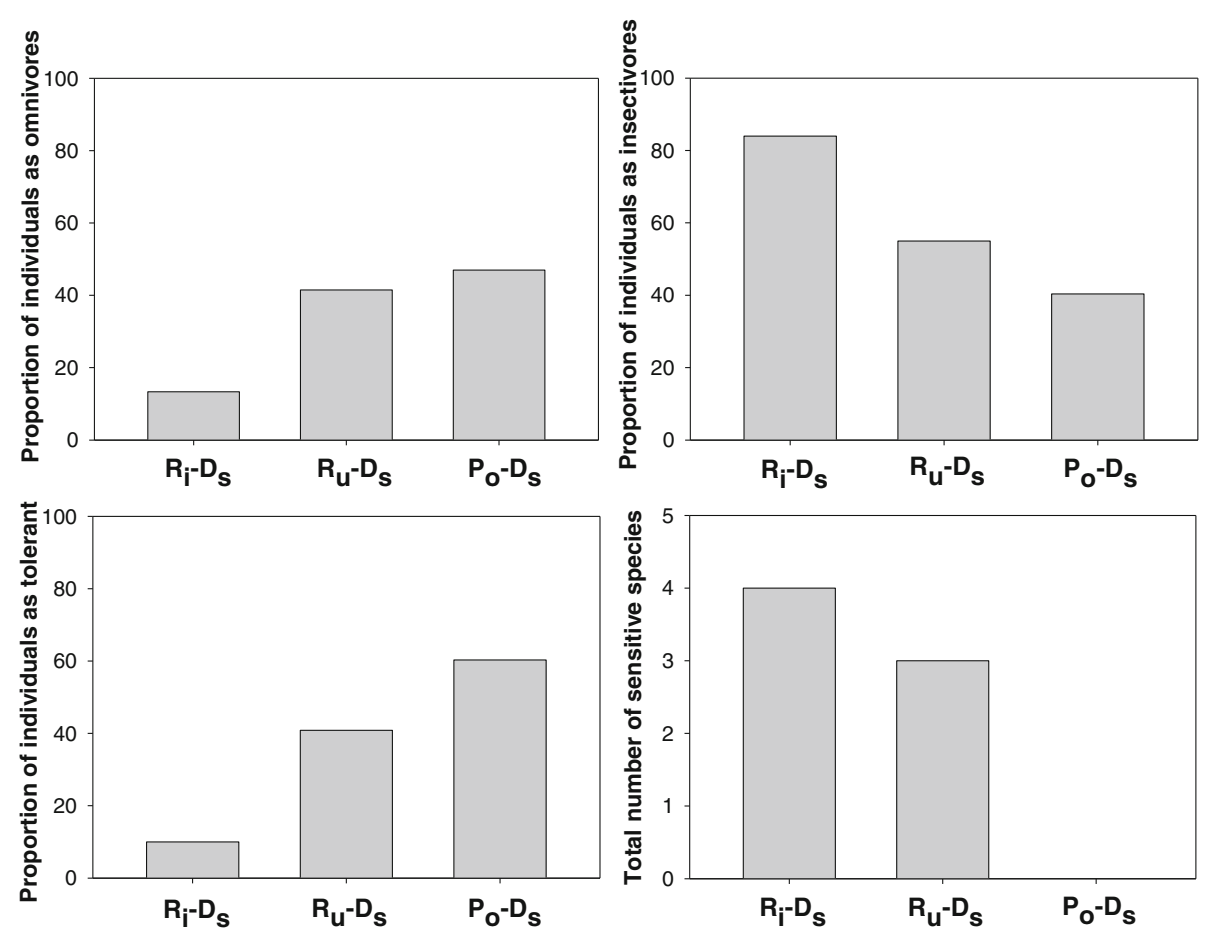

Fig. 5 The proportions of omnivores, insectivores, tolerant species, and sensitive species in three mesohabitats dominated by pools $\left(P_{\circ}-D_{s}\right)$, riffles $\left(R_{i}-D_{s}\right)$, and runs $\left(R_{u}-D_{s}\right)$ 
mesohabitat structure and land uses on the IBI, we used a multiple regression analysis. Data were log-transformed in order to follow the regression analysis requirements. Statistical analyses were performed using SigmaPlot (Systat Software Inc.).

\section{Results and discussion}

Responses of biological indicators on water chemistry

Responses of biological indicators, as a proportion of number of individuals in omnivore and insectivore species, were expressed on water chemistry (Figs. 2 and 3). The influx of nutrients of TP and TN via the watersheds into the streams altered the guild structure and abundance. The relative proportions of omnivores and insectivores individuals were directly determined by the magnitude of nutrients and organic matters (Fig. 2). When BOD, TP, and Chl were low, the omnivores caused a wide variation in the biological responses. However, when a threshold is reached under the chemical conditions of BOD $>5 \mathrm{mgL}^{-1}$, Chl $>5 \mu \mathrm{gL}^{-1}$, and $\mathrm{TP}>0.6 \mathrm{mgL}^{-1}$, the omnivores had positive responses to increased chemical contents and had negative responses in the TN:TP ratios $(>20)$ and Chl:TP ratios $(>0.02)$. In the meantime, no clear responses were observed in TN (Fig. 2). The opposite trend, however, was evident in the insectivore species. The proportions of insectivores were low when BOD, $\mathrm{TP}$, and CHL values were high, and high when these parameter values were low (Fig. 3), indicating that the proportions of insectivores had inverse functions with water pollutions. Values of BOD, as an indicator for organic matter pollution, and TP, as a nutrient pollution determined concentrations of sestonic CHL. These results are supported by previous findings (US EPA 1993; Kim and An 2015) that the proportions of sensitive and/or insectivore fish species decrease with
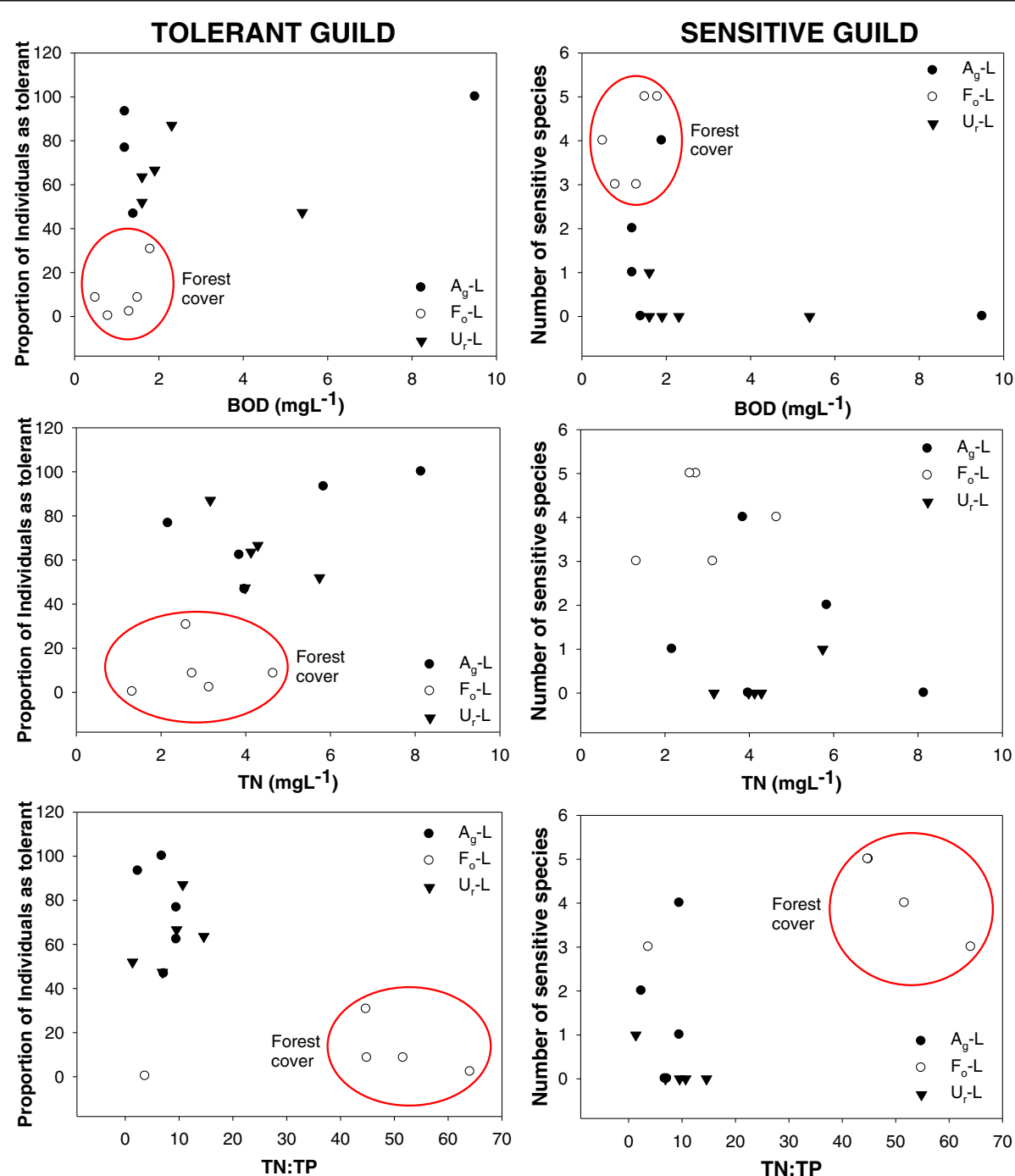

Fig. 6 Tolerant fish species observed in the three types of land use [agricultural $\left(A_{g}-L\right)$, forest $\left(F_{0}-L\right)$ and urban land $\left(U_{r}-L\right)$ ] 
nutrient enrichment and organic matter pollution, and vice versa in tolerant/omnivores species. Our results of trophic compositions vs chemical pollutions are in accordance with the typical trend observed in eutrophic waters (An et al. 2002; Drake and Pereira 2002). With an increase in the chemical pollution, sensitive species and insectivores were eliminated from the guild structures, resulting in massive emergence of an omnivorous population in the fish compositions (Lee, Han, et al. 2011a)

\section{Chemical water quality at mesohabitat and land-use scales}

The distribution and abundance of benthic species in three mesoscale habitats of pool, riffle, and run reach were analyzed in relation to the chemical gradients of water quality parameters (Fig. 4). As shown in Fig. 4, the pool reach with predominance in the mesoscale habitat had high values in nutrients, organic matters, and sestonic algae (BOD $>3 \mathrm{mgL}^{-1}$, Chl $>4.5 \mu \mathrm{gL}^{-1}$, TP $>0.4 \mathrm{mgL}^{-1}$, and $\left.\mathrm{TN}>4.5 \mathrm{mgL}^{-1}\right)$. In contrast, most sites dominated by riffles showed low nutrients and organic sestons (BOD $<1.5 \quad \mathrm{mgL}^{-1}, \quad \mathrm{Chl}<3.0 \quad \mu \mathrm{gL}^{-1}, \quad \mathrm{TP}$ $<0.35 \mathrm{mgL}^{-1}, \mathrm{TN}<3.1 \mathrm{mgL}^{-1}$ ) with a maximum of four benthic species. The run-reach dominant area had intermediate values between high and low chemical contents (Fig. 4). Observations of trophic guilds in three mesohabitats showed the lowest number of proportion of omnivores at the sampling sites dominated by riffles (13.3\%) and the highest at the reaches dominated by pools (47.0\%). In contrast, the insectivores displayed a maximum value at riffle reach $(84.0 \%)$, whereas the minimum was observed at the pool reach (40.4\%; Fig. 4). Observations of tolerant guilds showed that the proportion of tolerant individuals was low in the reaches dominated by riffles (10.0\%) and higher in the reaches dominated by pool (60.3\%). A maximum number of sensitive species were observed at the reaches dominated by riffles (4), while no sensitive species were observed at pools (Fig. 5).

The abundance of tolerant and sensitive species, as the number of individuals in the three types of land use showed clear patterns in chemical gradients (Fig. 6). The proportion of tolerant individuals were always $<40 \%$ in forest land-use regions and the contents of nutrients and organic matters were low (BOD $<2 \mathrm{mgL}^{-1}$, Chl $<4.0 \mu \mathrm{gL}^{-1}$, TP $<0.5 \mathrm{mgL}^{-1}$ ). The opposite pattern was observed in agricultural and urban land-use regions where the proportions of the tolerant species were $>40 \%$ (Fig. 6). The number of sensitive species ranged from three to five distributed in a short chemical ranges (BOD $<2 \mathrm{mgL}^{-1}$, Chl $<4.0 \mu \mathrm{gL}^{-1}$, TP $<0.5 \mathrm{mgL}^{-1}$ ). In most of the cases, no sensitive species were observed in the urban-land-use region (Fig. 6). Observation of trophic guilds in three types of land uses (Fig. 7) showed the lowest number of proportion of omnivores at forest
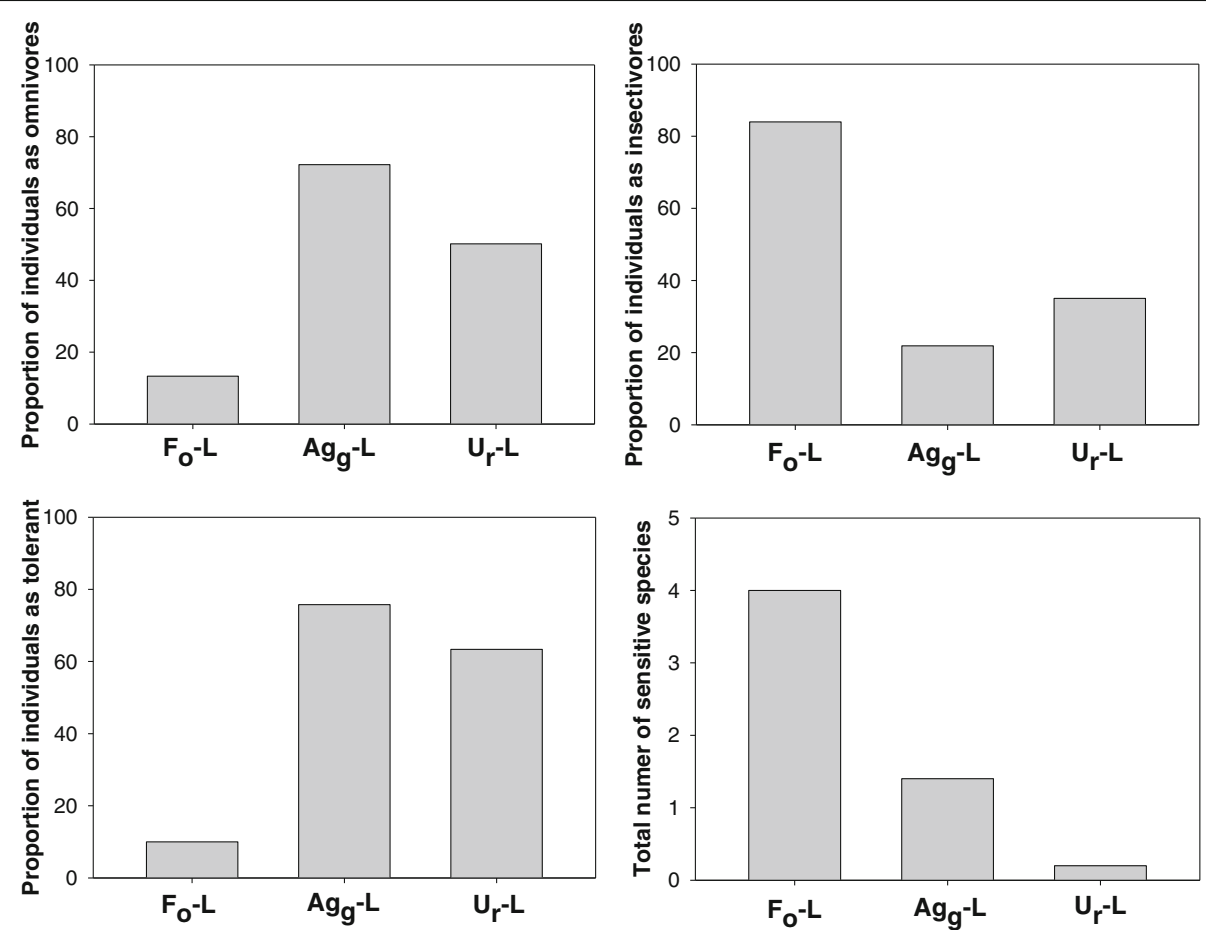

Fig. 7 The proportions of omnivores, insectivores, tolerant species, and sensitive species in the three types of lands [agricultural $\left(A_{g}-L\right)$, forest $\left(F_{0}-L\right)$, and urban land $\left.\left(U_{r}-L\right)\right]$ 
lands (13.32) and the highest at the reaches dominated by agricultural lands (72.2\%), while insectivores displayed a maximum value at forest lands $(84.0 \%)$, whereas the minimum was observed at agricultural lands (21.9\%). Observations of tolerant guilds showed that the proportion of tolerant individuals was low in the reaches dominated by forest region (9.9\%) and higher in the regions dominated by agricultural lands (75.8\%). A maximum number of sensitive species were observed in the forest lands (4.0\%), whereas low numbers of sensitive species were observed in the urban regions $(0.2 \%)$. Our results of fish guilds in the relation to the land-use pattern are supported by previous studies (Wang et al. 2000; Lyons 2006), that urban watershed or riparian urban zones had stronger negative impacts on stream fishes than agricultural land-use regions.
Chemical water quality variations along the stream orders Nutrient contents varied with stream order in the watershed. Overall, BOD values ranged from 3.59 to $7.38 \mathrm{mgL}^{-1}$, with high values in the first and second order, suggesting that organic materials are more concentrated in the upper stream (Fig. 8). This phenomenon might have been related to organic matter sources from the detritus of forest leaves, as the river continuum concept suggested.

Sestonic Chl increased with stream order ranging from 2.51 to $5.94 \mu \mathrm{gL}^{-1}$. Surprisingly, total phosphorus concentrations decreased along stream order from $1.34 \mathrm{mgL}^{-1}$ in the first order to $0.54 \mathrm{mgL}^{-1}$ in the sixth order. Concentrations of total nitrogen were always $>1.0 \mathrm{mgL}^{-1}$ and did not show significant differences along the stream order, indicating that nitrogen is rich in this watershed regardless
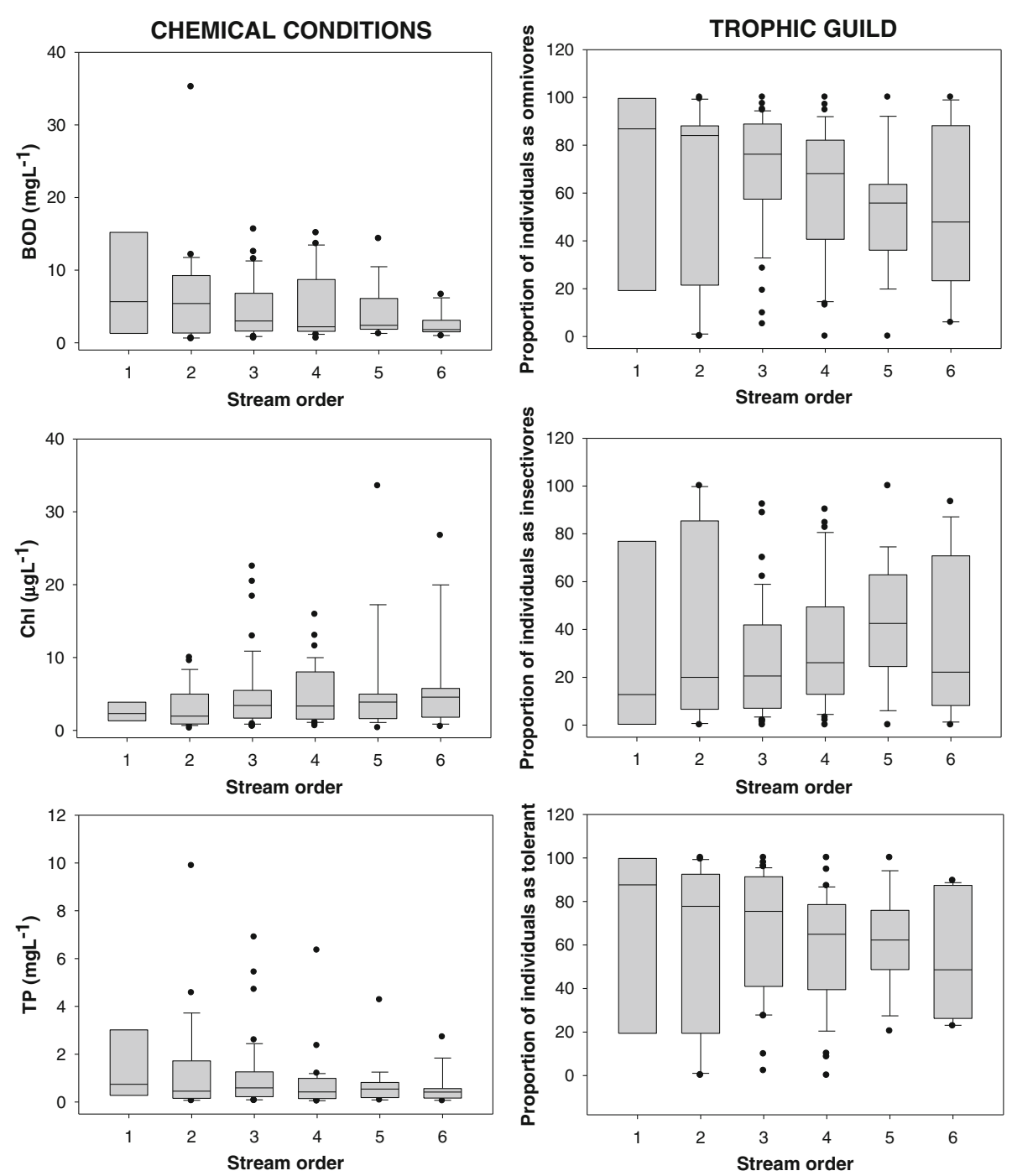

Fig. 8 Water quality and trophic guilds against the stream order in Geum River watershed 

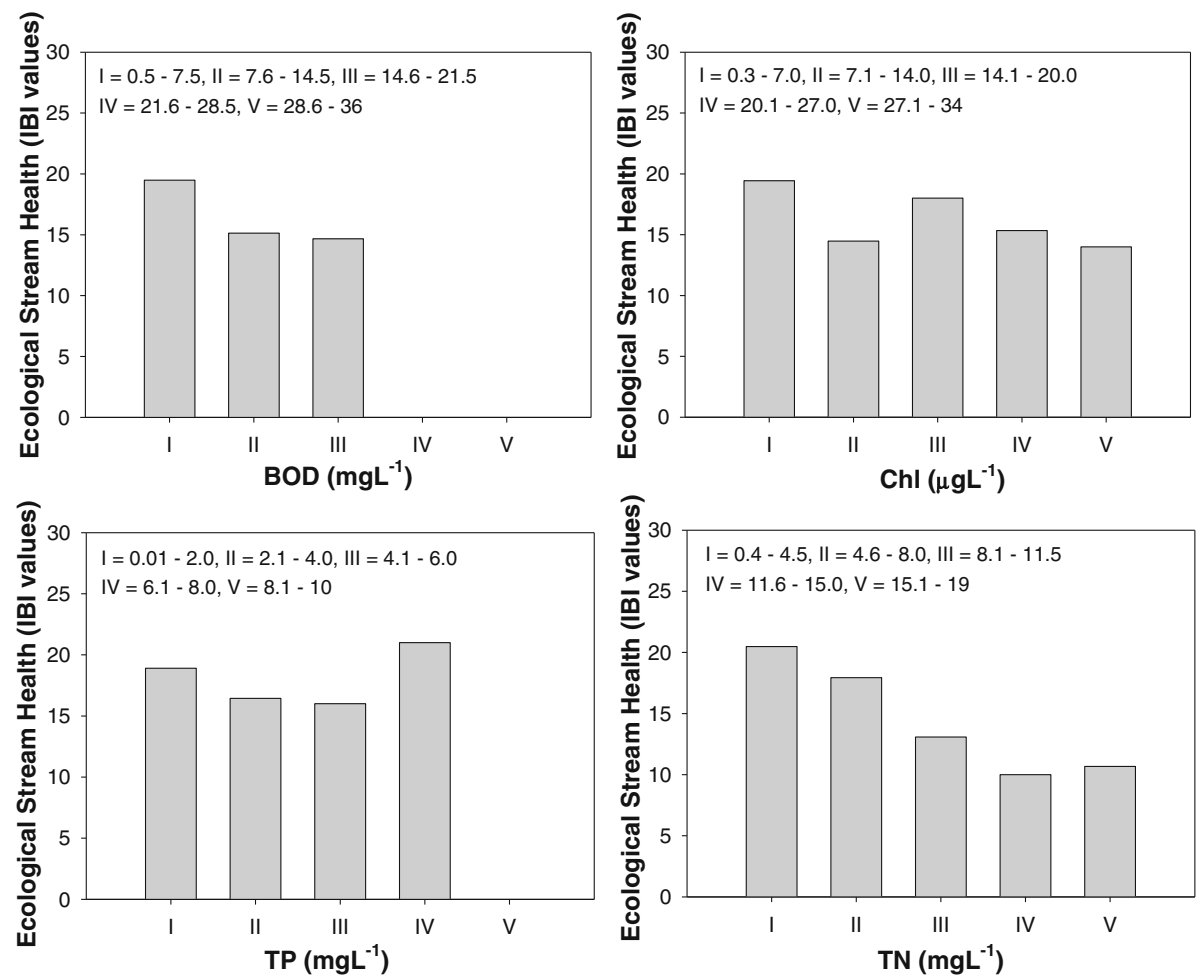

Fig. 9 Ecological stream health (as IBI values) in the Geum River watershed against the nutrient concentrations $(n=150)$

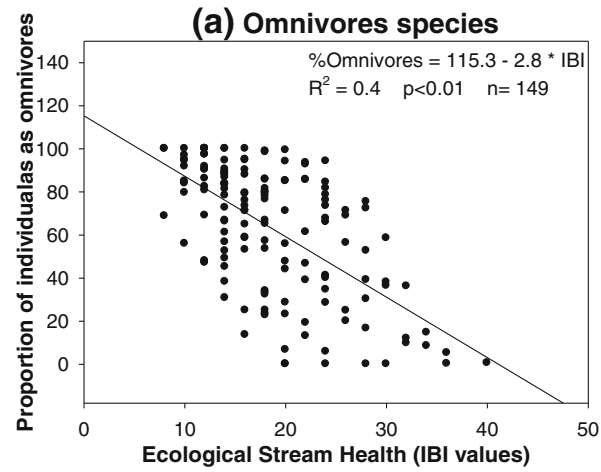

(c) Sensitive species

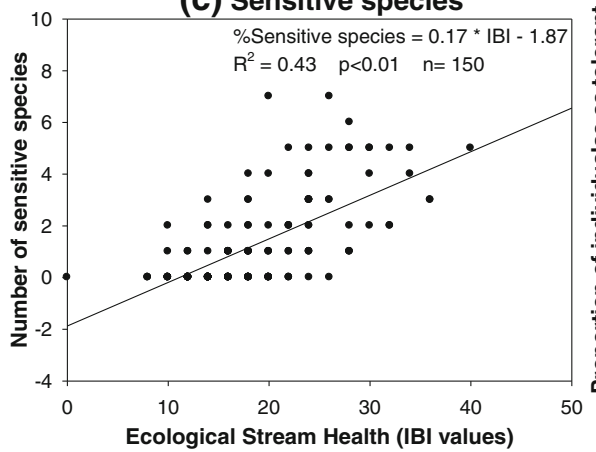

Fig. 10 Regression analysis of trophic guild against the ecological stream health, as values of the index of biological integrity (IBI), in the Geum River watershed (used the entire dataset, $n=150$ ) (b) Insectivores species

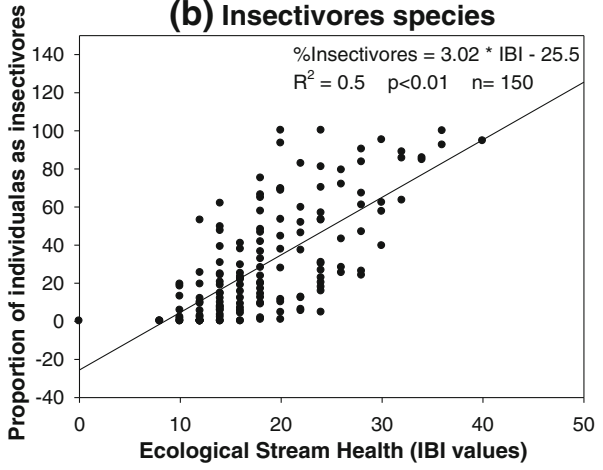

(d) Tolerant species

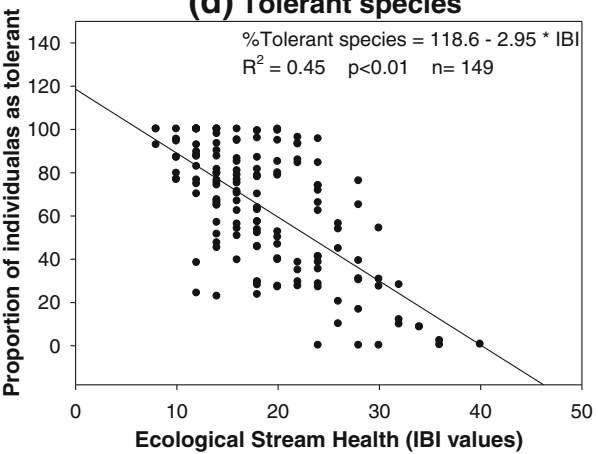


of locations. In the same way, trophic guild did not display important differences along stream order.

\section{Multi-metric stream health assessment model of the index of biological integrity}

Values of the IBI showed a large variation depending on the sampling site in the watershed (Fig. 9). Overall, the IBI model values ranged from 14.8 to 34 and averaged $22.6(n=30$, standard error $=8.13$; Table 1$)$. Streams dominated by riffles and forest land-use reaches showed the highest IBI values $(34 \pm 0.65)$, while pool-dominated streams and surrounded by urban land showed the lowest values $(16.8 \pm 1.35$ and $14.8 \pm 0.98$, respectively; Fig. 9). This result suggests the importance of the mesoscale habitat and land-use pattern in the ecological stream health. None of the study sites, however, could be judged as in an "excellent" condition. Plots of IBI values against nutrient concentrations did not show a clear correlation with the exception of BOD and total nitrogen where the IBI values decreased with higher nutrient concentrations (Fig. 9). It is thus evident that the nutrients as well as organic matters reflected by BOD in the watersheds have an influence on the biological integrity. Strong correlations were observed between trophic guild and IBI. The increase of omnivores and tolerant species reduce the biological integrity in the stream, while a rise in insectivores and sensitive species reflected an increase in the IBI values (Fig. 10).

\section{Fish fauna and compositions}

The stream health, based on the multi-metric IBI fish model, was closely associated with community structures, and the result is shown well in fish compositions of tolerant species and trophic species. In this study, the total number of species and the individuals sampled were 44 and 4978, respectively, from the watershed of the Geum River. The dominant fishes with greater than 0.01 in relative abundance (R.A.) are shown in Table 2 in Geum River. The highest dominant species was Zacco koreanus, which composed about $72 \%$ of the total in riffle-dominant sites, and then followed by Zacco platypus (62\%) in agricultural lands, Microphysogobio jeoni

Table 2 Fish species and their tolerance and trophic guilds with a high relative abundance (R.A. $\geq 0.01$ ) on the mesohabitat types and land-use patterns

\begin{tabular}{|c|c|c|c|c|c|c|c|c|c|}
\hline \multirow[t]{2}{*}{ Species } & \multirow[t]{2}{*}{ Tolerant guild } & \multirow[t]{2}{*}{ Trophic guild } & \multicolumn{3}{|c|}{ Mesohabitat types } & \multicolumn{3}{|c|}{ Land-use pattern } & \multirow[t]{2}{*}{ Average R.A. } \\
\hline & & & $\mathrm{R}_{\mathrm{i}}-\mathrm{D}_{\mathrm{s}}$ & $\mathrm{R}_{\mathrm{u}}-\mathrm{D}_{\mathrm{s}}$ & $P_{0}-D_{s}$ & $F_{0}-L$ & $A_{g}-L$ & $U_{r}-L$ & \\
\hline Zacco koreanus & SS & । & 0.722 & 0.000 & 0.000 & 0.722 & 0.035 & 0.000 & 0.246 \\
\hline Zacco platypus & IS & O & 0.059 & 0.186 & 0.021 & 0.059 & 0.620 & 0.273 & 0.203 \\
\hline Microphysogobio jeoni & IS & 1 & 0.000 & 0.000 & 0.472 & 0.000 & 0.000 & 0.000 & 0.079 \\
\hline Pseudogobio esocinus & IS & 1 & 0.023 & 0.132 & 0.009 & 0.023 & 0.055 & 0.181 & 0.071 \\
\hline Squalidus japonicus coreanus & TS & $\mathrm{O}$ & 0.000 & 0.003 & 0.116 & 0.000 & 0.030 & 0.106 & 0.042 \\
\hline Opsarichthys uncirostris amurensis & TS & C & 0.001 & 0.033 & 0.095 & 0.001 & 0.034 & 0.048 & 0.035 \\
\hline Hamibarbus labeo & TS & 1 & 0.000 & 0.042 & 0.131 & 0.000 & 0.002 & 0.022 & 0.033 \\
\hline Rhynchocypris oxycephalus & SS & 1 & 0.086 & 0.000 & 0.000 & 0.086 & 0.000 & 0.000 & 0.029 \\
\hline Carassius auratus & TS & $\mathrm{O}$ & 0.000 & 0.042 & 0.003 & 0.000 & 0.053 & 0.062 & 0.027 \\
\hline Pungtungia herzi & IS & 1 & 0.019 & 0.105 & 0.000 & 0.019 & 0.000 & 0.004 & 0.025 \\
\hline Squalidus gracilis majimae & IS & 1 & 0.003 & 0.015 & 0.000 & 0.003 & 0.032 & 0.079 & 0.022 \\
\hline Hemiculter eigenmanni & TS & $\mathrm{O}$ & 0.000 & 0.036 & 0.000 & 0.000 & 0.037 & 0.053 & 0.021 \\
\hline Hamibarbus longirostris & IS & 1 & 0.020 & 0.009 & 0.006 & 0.020 & 0.037 & 0.022 & 0.019 \\
\hline Microphysogobio yaluensis & IS & O & 0.012 & 0.054 & 0.000 & 0.012 & 0.009 & 0.000 & 0.015 \\
\hline Acheilognathus lanceolatus & is & $\mathrm{O}$ & 0.008 & 0.051 & 0.006 & 0.008 & 0.002 & 0.009 & 0.014 \\
\hline Squaliobarbus curriculus & IS & $\mathrm{O}$ & 0.000 & 0.012 & 0.047 & 0.000 & 0.000 & 0.018 & 0.013 \\
\hline Sarcocheilichthys variegatus wakiyae & IS & 1 & 0.000 & 0.069 & 0.000 & 0.000 & 0.002 & 0.000 & 0.012 \\
\hline Micropterus salmoides ${ }^{a}$ & TS & C & 0.003 & 0.012 & 0.003 & 0.003 & 0.002 & 0.048 & 0.012 \\
\hline Rhinogobius brunneus & IS & I & 0.001 & 0.027 & 0.003 & 0.001 & 0.001 & 0.031 & 0.011 \\
\hline Iksookimia koreensis & IS & 1 & 0.011 & 0.039 & 0.000 & 0.011 & 0.001 & 0.000 & 0.010 \\
\hline Tridentiger brevispinis & IS & । & 0.000 & 0.006 & 0.047 & 0.000 & 0.001 & 0.004 & 0.010 \\
\hline
\end{tabular}

High R.A. values in each site are set in italics

TS tolerant species, IS intermediate species, SS sensitive species, $C$ carnivores, $O$ omnivores, $I$ insectivores

${ }^{\mathrm{a}}$ Exotic species 
(47\%) in pool-dominant sites, and Pseudogobio esocinus (13\%) in run-dominant sites. The fish fauna suggest that the dominant species are composed of intermediate species on the mesohabitat or land use. Tolerance guild analysis showed that intermediate species dominated the lotic ecosystems we studied. The intermediate species constituted 38.4\% (23 species and 1910 individuals), while the sensitive species represented only 52.3\% (6 species and 2602 individuals) of the Relative Abundance. The tolerant species constituted 9.3\% (15 species and 466 individuals) of the R.A. Trophic guild analysis also confirmed that the fish reflected the water quality of the system. The omnivores dominated the ecosystem. The proportion of omnivore species, as a number of individuals, was $28.2 \%$ ( 21 species and 1402 individuals), and in contrast, insectivore species was $67.6 \%$ (17 species and 3367 individuals). The proportion of the carnivore species was 4.2\% (6 species and 209 individuals), while herbivores and filter feeders were not observed. The ecological distribution of the tolerance and the trophic guilds was associated with the water quality parameters. Insectivorous species rapidly decreased $\left(R^{2}=0.2, p<0.01\right.$, $n=147)$ with degradation in water quality $(B O D)$; while omnivorous species dominated the system $\left(R^{2}=0.16\right.$, $p<0.01, n=144$ ) (Figs. 2 and 3). Additionally, three major exotic species were observed, largemouth bass (Micropterus salmoides), bluegill (Lepomis macrochirus), and Japanese crucian carp (Carassius cuvieri). M. salmoides was distributed in all stream studies, while $L$. macrochirus and C. cuvieri were found in pool-dominated streams and agricultural land, respectively.

\section{Conclusions}

Our data demonstrated that the analysis of mesohabitat structures of pool, riffle, and run reaches is important in the determination of fish guilds and biological integrity in Geum-River Watershed. The mesoscale components influenced directly chemical water quality of nutrients and organic matter contents in the scale and these, then, determined the trophic and tolerance components of fish. Trophic guilds and tolerance guilds of fish were determined by land-use pattern and these determined the stream health, based on the Index of Biological Integrity. This study remarks the necessity to include additional variables to consider information provided by mesohabitats and land-use distributions within the selected stream stretch. Overall, our data suggest that land-use pattern and mesohabitat distribution are important factors to be considered for the trophic and tolerance fish compositions and chemical gradients as well as ecological stream health in the watershed.

\section{Acknowledgements}

This research is funded by the Daejeon Green Environment Center under the Research Development Program (Yr 2016), and the authors would like to acknowledge the assistance.

\section{Authors' contributions}

KG got a research project for the topic, and MS analyzed the data with KG. MS and KG wrote the manuscript and then edited together. All authors read and approved the final manuscript.

\section{Competing interests}

The authors declare that they have no competing interests.

Received: 10 July 2016 Accepted: 31 August 2016

Published online: 24 November 2016

\section{References}

An, K. G., Park, S. S., \& Shin, J. Y. (2002). An evaluation of a river health using the index of biological integrity along with relations to chemical and habitat conditions. Environment International, 28, 411-420.

An, K. G., Lee, J. Y., Bae, D. Y., Kim, J. H., Hwang, S. J., Won, D. H., Lee, J. K., \& Kim, C. S. (2006). Ecological assessments of aquatic environment using multi-metric model in major nationwide stream watersheds. Journal of Korean Society on Water Quality, 22, 796-804.

APHA. (1999). Standard Methods for the Examination of Water and Wastewater (19th ed.). Washington DC: American Public Health Association.

Casatti, L., \& Teresa, F. B. (2012). Multimetric index based on fish fauna for the evaluation of the biotic integrity of streams at a mesohabitat scale. Acta Limnologica Brasiliensia, 24, 339-350.

Chung, S. W., Ko, I. H., \& Kim, Y. K. (2008). Effect of reservoir flushing on downstream river water quality. Journal of Environmental Management, 86, 139-147.

Drake, M. T., \& Pereira, D. L. (2002). Development of a fish-based index of biotic integrity for small inland lakes in Central Minnesota. North American Journal of Fisheries Management, 22, 1105-1123.

European Commission. (2000). Directive 2000/60/EC of the European Parliament and of the Council establishing a framework for community action in the field of water policy. Official Journal, L327, 72 .

Ganasan, V., \& Hughes, R. M. (1998). Application of an index of biological integrity (IBI) to fish assemblages of the rivers Khan and Kshipra (Madhya Pradesh), India. Freshwater Biology, 40, 367-383.

Gelwick, F. P. (1990). Longitudinal and temporal comparisons of riffle and pool fish assemblage in a northeastern Oklahoma Ozark stream. Copeia 4, 1072-1082

Gosselin, M. P., Maddock, I., \& Petts, G. (2012). Mesohabitat use by brown trout (Salmo trutta) in a small groundwater-dominated stream. River Research and Applications, 28, 390-401.

Griffith, M. B., Hill, B. H., McCormick, F. H., Kaufmann, P. R., Herlihy, A. T., \& Selle, A. R. (2005). Comparative application of indices of biotic integrity based on periphyton, macroinvertebrates, and fish to southern Rocky Mountain streams. Ecological Indicators, 5, 117-136.

Harris, J. H. (1995). The use of fish in ecological assessments. Australian Journal of Ecology, 20, 65-80.

Harris, J. H., \& Silveira, R. (1999). Large-scale assessments of river health using an index of biotic integrity with low-diversity fish communities. Freshwater Biology, 41, 235-252.

Hocutt, C. H., Johnson, P. N., Hay, C., \& van Zyl, B. J. (1994). Biological basis of water quality assessments: the Kavango River, Namibia. Review of Hydrobiology Tropical, 27, 361-384.

Hughes, R. M. (1995). Defining acceptable biological status by comparing with reference conditions. In T. P. Simon (Ed.), Biological assessment and criteria: tools for water resource planning and decision making (Davis WS (pp. 31-47). Boca Raton: CRC Press.

Huqueny, B., Camara, S., Samoura, B. \& Magassouba, M. (1996). Applying an index of biotic integrity based on fish communities in a West African river. Hydrobiology, 331, 71-78.

Jaramillo-Villa, U., \& Caramaschi, E. (2008). Índices de integridade biótica usando peixes de agua doce: uso nas regiões tropical e subtropical. Oecologia Brasiliensis, 12, 442-462.

Karr, J. R. (1981). Assessment of biotic integrity using fish communities. Fisheries, $6,21-27$

Karr, J. R., Fausch, K. D., Angermeier, P. L., Yant, P. R., \& Schlosser, I. J. (1986). Assessing biological integrity in running water: a method and its rationale (Vol. 5, p. 28). Champaign: Illinois National History Survey. Special Publication.

Kennard, M. J., Arthington, A. H., Pusey, B. J., \& Harch, B. D. (2005). Are alien fish a reliable indicator of river health? Freshwater Biology, 50, 174-193. 
Kim IS (1995). Conservation and distribution of endangered freshwater fish. Symp Korean Ecol, 20, 2-3.

Kim, I. S. (1997). Encyclopedia of Korean animals and plants. Animal (Freshwater fish), $37,629$.

Kim, J. Y., \& An, K. G. (2015). Integrated ecological river health assessments, based on water chemistry, physical habitat quality and biological integrity. Water, 7, 6378-6403.

Kleynhans, C. J. (1999). The development of a fish index to assess the biological integrity of South African rivers. Water SA, 25, 265-278.

Langeani, F., Casatti, L., Gameiro, H. S., Belluco, A., \& Rossa-Feres, D. (2005). Riffle and pool fish communities in a large stream of southeastern Brazil. Neotropical Ichthyology, 3, 305-311.

Lee, S. H., \& Hwang, J. J. (2013). Application of grouping method to select priority restoration streams in Geumgang Watershed based on analysis of pollution factors. Journal of the Korean Society of Water and Wastewater, 27, 661-669.

Lee, J. H., Han, J. H., Kumar, H. K., Choi, J. K., Byeon, H. K., Choi, J., Kim, J. K., Jang, M. H., Park, H. K., \& An, K. G. (2011). National-level integrative ecological health assessments based on the index of biological integrity, water quality, and qualitative habitat evaluation index, in Korean rivers. Annales de Limnologie International Journal of Limnology, 47, S73-S89.

Lee, S. W., Hwang, S. J., Lee, J. K., Jung, D. I., Park, Y. J., \& Kim, J. T. (2011). Overview and application of the National Aquatic Ecological Monitoring Program (NAEMP) in Korea. Annales de Limnologie International Journal of Limnology, 47, S3-S14.

Lyons, J. (2006). A fish-based index of biotic integrity to assess intermittent headwater streams in Wisconsin, USA. Environmental Monitoring and Assessment, 122, 239-258.

Machado, N. G., Venticinque, E. M., \& Penha, J. (2011). Effect of environmental quality and mesohabitat structure on a biotic integrity index based on fish assemblages of Cerrado streams from Rio Cuiabá basin, Brazil. Brazilian Journal of Biology, 71, 577-586.

Noh, J. W., Choi, H. G., \& Lee, S. J. (2015). Water quality projection in the Geum River basin in Korea to support integrated basin-wide water resources management. Environment and Earth Science, 73, 1745-1756.

Oberdorff, T., \& Hughes, R. M. (1992). Modification of an index of biotic integrity based on fish assemblages to characterize rivers of the Seine Basin, France. Hydrobiologia, 228, 117-130.

Ohio, E. P. A. (1989). Biological criteria for the protection of aquatic life. Standardized biological field sampling and laboratory method for assessing fish and macroinvertebrate communities (Vol. III). Columbus: Ohio EPA Division of Water Quality Monitoring and Assessment Surface Water Section.

Pichon, C., Georges, G., Boët, P., Baudry, J., Faure, T., \& Goreaud, F. (2006). A spatially explicit resource-based approach for managing stream fishes in riverscapes. Environmental Management, 37, 322-335.

Plafkin JL, Babour MT, Porter KD, Gross SK, Hughes RM. 1989. Rapid bioassesment protocols for use in streams and rivers: benthic macroinvertebrate and fish. Environmental Protection Agency (EPA), Washington, DC, EPA-444/4-89-001.

Prepas, E. E., \& Rigler, F. A. (1982). Improvements in qualifying the phosphorus concentration in lake water. Canadian Journal of Fisheries and Aquatic Sciences, 39, 822-829.

Roset, N., Grenouillet, G., Goffaux, D., Pont, D., \& Kestemont, P. (2007). A review of existing fish assemblage indicators and methodologies. Fisheries Management and Ecology, 14, 393-405.

Sanders, R. E., Milter, R. J., Yondr, C. O., \& Rankin, E. T. (1999). The use of external deformities, erosion, lesions, and tumors (DELT anormalies) in fish assemblages for characterizing aquatic resources: a case study of seven Ohio streams. In T. P. Simon (Ed.), Assessing the sustainability and biological integrity of water resources using fish communities (pp. 225-245). Washington, DC: CRC Press.

Sartory, D. P., \& Grobbelaar, J. U. (1984). Extraction of chlorophyll-a from freshwater phytoplankton for spectrophotometric analysis. Hydrobiologia, $114,177-187$.

Schmutz, S., Cowx, I. G., Haidvogl, G., \& Pont, D. (2007). Fish-based methods for assessing European running waters: a synthesis. Fisheries Management and Ecology, 14, 369-380.

Shim, M. J., Yang, Y. M., Oh, D. Y., Lee, S. H., \& Yoon, Y. Y. (2015). Spatial distribution of heavy metal accumulation in the sediments after dam construction. Environmental Monitoring and Assessment, 187, 733-746.

Teresa, F. B., \& Casatti, L. (2010). Importância da vegetação ripária em região intensamente desmatada no sudeste do Brasil: um estudo com peixes de riacho. Pan-American Journal of Aquatic Sciences, 5, 444-453.
US EPA. 1993. Fish field and laboratory methods for evaluating the biological integrity of surface waters. EPA 600-R-92-111. Environmental Monitoring systems Laboratory-Cincinnati office of Modeling, Monitoring systems, and quality assurance. Office of Research Development, US EPA, Cincinnati, $\mathrm{OH} 45268$.

Wang, L., Lyons, J., Kanehl, P., Bannerman, R., \& Emmons, E. (2000). Watershed urbanization and changes in fish communities in southeastern Wisconsin streams. Journal of the American Water Resources Association, 36, 1173-1189.

Zhu, D., \& Chang, J. (2008). Annual variations of biotic integrity in the upper Yangtze River using an adapted index of biotic integrity (IBI). Ecological Indicators, 8, 564-572.

\section{Submit your next manuscript to BioMed Central and we will help you at every step:}

- We accept pre-submission inquiries

- Our selector tool helps you to find the most relevant journal

- We provide round the clock customer support

- Convenient online submission

- Thorough peer review

- Inclusion in PubMed and all major indexing services

- Maximum visibility for your research

Submit your manuscript at www.biomedcentral.com/submit 